\title{
THE FREE AMINO ACID CONTENT OF UTERINE FLUIDS AND BLOOD SERUM IN THE COW
}

\author{
M. L. FAHNING,* R. H. SCHULTZ* AND E. F. GRAHAM \\ Department of Dairy Husbandry, University of Minnesota, \\ St Paul, Minnesota, U.S.A. \\ (Received 18th February 1966, revised 29th April 1966)
}

\begin{abstract}
Summary. Uterine fluid and blood serum samples were collected from 100 adult dairy cows during various stages of the oestrous cycle and analysed for their free amino acid content. A total of twenty-five free amino acids and amino compounds were identified in uterine fluids while only twenty-three were identified in blood serum. The concentration of the total and of most of the individual free amino acids was greater in uterine fluid than in blood serum at all stages of the oestrous cycle. The total content of free amino acids and the concentration of several individual free amino acids in uterine fluids showed cyclical variations. The significance of free amino acids in uterine fluids is discussed.
\end{abstract}

\section{INTRODUCTION}

The importance of the luminal fluids in the female reproductive tract has been widely recognized. These fluids provide the biochemical environment in which fertilization and early embryonic development occur. The presence of a fluid in the uterus has been reported by many workers in a variety of species. Hammond (1927) reported a thin lymph-like fluid to be present on the surface of the mucosa of the bovine uterus during oestrus. Olds \& VanDemark (1957a, b) recovered fluids from uteri of cows following slaughter, while Heap (1962) and Heap \& Lamming (1962) recovered flushings from uteri of live cows for various chemical analyses. These workers reported changes in the concentration of certain constituents during the oestrous cycle.

Gregoire, Gonsakdi \& Rakoff (1961) utilized two-dimensional paper chromatography to evaluate the free amino acid concentrations in fluids obtained from ligated rabbit uteri. These workers observed changes in the concentration of certain amino acids after ovariectomy and subsequent treatment withoestrogen and progesterone. However, no investigations of the free amino acid content of bovine uterine fluids during the oestrous cycle have been previously reported. The present study was undertaken to compare the free amino acid content of uterine fluids and blood serum during various stages of the oestrous cycle in the cow.

Scientific Jr. Series Paper No. 5883, Minnesota Agricultural Experiment Station.

* Present address: Department of Veterinary Obstetrics and Gynecology, College of Veterinary Medicine, University of Minnesota, St Paul, Minnesota 55101. 


\section{MATERIALS AND METHODS}

Uterine fluid was collected for analysis from 100 adult dairy cows using the technique of Fahning, Schultz \& Graham (1966). The technique involves the aspiration of the fluids using a small vinyl catheter which is passed into the uterus through a uterine infusion pipette. This method was developed to provide uterine fluid samples of adequate quantity and quality for chemical analyses. It has the advantage of not requiring procedures such as uterine ligation or flushing which have been shown to alter the concentration of chemical constituents in the uterine fluids. The cows used in the study were selected to meet the following requirements: (1) they had all had at least one pregnancy; (2) all females had calved normally at least 30 days previously and had not been mated, and (3) all were judged to be clinically normal by rectal palpation just before collecting uterine fluids. Cows classified as 'repeat-breeders' were required to meet all the above criteria except that they had been mated at least three times and had not conceived.

TABLE 1

EXPERIMENTAL GROUPS

\begin{tabular}{l|c}
\hline \multicolumn{1}{c|}{ Group* $^{*}$} & No. of cows \\
\hline Day 1 (oestrus) & 13 \\
Day 2 & 11 \\
Days 3 to 4 & 11 \\
Days 5 to 7 & 10 \\
Days 8 to 10 & 10 \\
Days 11 to 13 & 8 \\
Days 14 to 16 & 9 \\
Days 17 to 18 & 10 \\
Days 19 to 20 & 10 \\
\hline 'REPEAT-BREEDER' cows & 8 \\
Day 1 (oestrus) & \\
\hline
\end{tabular}

* Group based on day of oestrous cycle at which time the uterine fluid collections were made.

At the time of uterine fluid collection, blood samples were also taken by jugular venipuncture. The blood was allowed to clot and the serum separated by centrifugation. All uterine fluid and blood serum samples were stored in liquid nitrogen $\left(-196^{\circ} \mathrm{C}\right)$ until analysis. Samples of uterine fluid were centrifuged at $10,000 \mathrm{rev} / \mathrm{min}$ for $10 \mathrm{~min}$ immediately after thawing to separate the cellular elements present in the fluids.

Due to the small volumes of uterine fluid obtained from each cow, it was necessary to pool the samples from several cows to obtain a sufficient quantity for analysis. The samples were grouped as shown in Table 1. The pooled samples of uterine fluid and blood serum were prepared by using equal volumes of uterine fluid and of blood serum from each cow. From the pooled samples, a volume of $5 \mathrm{ml}$ of uterine fluid and of blood serum was used for all groups except Days 5 to 7 and Days 8 to 10; in these instances $3.75 \mathrm{ml}$ was used due to the small volume of uterine fluid available. 
Precipitation of protein in the samples was accomplished by the addition of 5 vol. $1 \%$ picric acid to 1 vol. of sample fluid. After mixing and centrifugation $(10,000 \mathrm{rev} / \mathrm{min}$ for $10 \mathrm{~min})$ the supernatant was recovered. The excess picric acid was removed by passing the supernatant through a column of Dowex 2-X10 type resin in the chloride form (The Dow Chemical Company, Midland, Michigan, U.S.A.) under a pressure of $1 \mathrm{lb} / \mathrm{in}^{2}$. The column and resin bed was washed with five $3 \mathrm{ml}$ vol. of $0.02 \mathrm{~N}-\mathrm{HCl}$. The effluent was

TABLE 2

CONTENT OF TOTAL FREE AMINO ACIDS AND AMINO COMPOUNDS IN BOVINE UTERINE FLUID COLLEGTED AT DIFFERENT PERIODS OF THE OESTROUS GYGLE $(\mu \mathrm{M} / \mathrm{ml})$

\begin{tabular}{|c|c|c|c|c|c|c|c|c|c|c|}
\hline \multirow[b]{2}{*}{ Amino acid } & \multicolumn{10}{|c|}{ Days of oestrous cycle } \\
\hline & 1 & $1-R B^{*}$ & 2 & $\begin{array}{c}3 \text { to } \\
4\end{array}$ & $\begin{array}{c}5 \text { to } \\
7\end{array}$ & $\begin{array}{r}8 \text { to } \\
10\end{array}$ & $\begin{array}{c}11 \text { to } \\
13\end{array}$ & $\begin{array}{c}14 \text { to } \\
16\end{array}$ & $\begin{array}{c}17 \text { to } \\
18\end{array}$ & $\begin{array}{r}19 \text { to } \\
20\end{array}$ \\
\hline Aspartic acid & $0 \cdot 19$ & 0.22 & 0.40 & $0 \cdot 32$ & $0 \cdot 37$ & $0 \cdot 60$ & 0.38 & 0.56 & 0.70 & 0.55 \\
\hline Threonine & 0.02 & 0.03 & 0.07 & $\mathrm{~N}$ & 0.04 & $0 \cdot 15$ & 0.07 & $0 \cdot 17$ & 0.10 & $0 \cdot 13$ \\
\hline Serine & $0 \cdot 10$ & $0 \cdot 10$ & $0 \cdot 17$ & 0.03 & $0 \cdot 16$ & 0.47 & 0.23 & 0.43 & 0.31 & 0.47 \\
\hline $\begin{array}{l}\text { Asparamine- } \\
\text { glutamine }\end{array}$ & $0 \cdot 23$ & $0 \cdot 25$ & 0.25 & 0.07 & 0.07 & 0.67 & 0.08 & 0.27 & $0 \cdot 12$ & 0.08 \\
\hline Proline & 0.12 & 0.04 & 0.16 & $0 \cdot 12$ & $0 \cdot 20$ & 0.26 & 0.22 & 0.26 & 0.46 & 0.62 \\
\hline Glutamic acid & $0 \cdot 73$ & 0.70 & $1 \cdot 49$ & 1.34 & 1.38 & 1.34 & 1.31 & 1.74 & 1.70 & 1.56 \\
\hline Glycine & 0.89 & $0 \cdot 80$ & 1.49 & 1.77 & $3 \cdot 27$ & $4 \cdot 42$ & 1.94 & 1.95 & 1.81 & 1.56 \\
\hline Alanine & 0.51 & $0 \cdot 48$ & $0 \cdot 66$ & $0 \cdot 72$ & 0.98 & 1.41 & 1.01 & $1 \cdot 10$ & 1.21 & 1.03 \\
\hline Valine & $0 \cdot 12$ & $0 \cdot 12$ & $0 \cdot 20$ & 0.20 & 0.30 & 0.41 & 0.34 & 0.37 & 0.41 & $0 \cdot 14$ \\
\hline Cystine & $0 \cdot 12$ & 0.26 & 0.04 & 0.38 & Trace & $\mathrm{N}$ & $\mathrm{N}$ & $\mathrm{N}$ & $\mathrm{N}$ & $\mathrm{N}$ \\
\hline Methionine & 0.02 & 0.01 & 0.01 & Trace & 0.08 & 0.07 & 0.05 & 0.04 & 0.02 & 0.02 \\
\hline Isoleucine & 0.07 & 0.06 & $0 \cdot 10$ & 0.08 & 0.15 & 0.22 & $0 \cdot 17$ & 0.19 & 0.20 & $0 \cdot 11$ \\
\hline Leucine & $0 \cdot 11$ & $0 \cdot 10$ & 0.18 & $0 \cdot 15$ & 0.24 & 0.54 & 0.36 & 0.32 & 0.46 & $0 \cdot 14$ \\
\hline Tyrosine & 0.07 & 0.07 & 0.09 & $0 \cdot 11$ & 0.12 & 0.22 & $0 \cdot 17$ & 0.21 & 0.22 & 0.05 \\
\hline Phenylalanine & 0.05 & 0.05 & 0.08 & 0.09 & $0 \cdot 10$ & 0.20 & $0 \cdot 13$ & $0 \cdot 16$ & $0 \cdot 19$ & 0.04 \\
\hline Lysine & 0.07 & $0 \cdot 13$ & 0.03 & 0.23 & 0.06 & Trace & Trace & 0.37 & $\mathrm{~N}$ & Trace \\
\hline Histidine & 0.04 & 0.05 & $0 \cdot 10$ & 0.08 & $\mathrm{~N}$ & $0 \cdot 11$ & 0.09 & $0 \cdot 10$ & $0 \cdot 13$ & 0.04 \\
\hline Arginine & 0.02 & $0 \cdot 01$ & 0.04 & Trace & $\mathbf{N}$ & 0.04 & 0.06 & 0.07 & 0.05 & $0 \cdot 10$ \\
\hline Taur & 0.72 & 0.70 & 1.36 & $1 \cdot 24$ & 1.69 & 1.57 & 0.62 & 0.77 & 0.53 & 0.66 \\
\hline Citrulline & $\mathrm{N}$ & $\mathrm{N}$ & $\mathrm{N}$ & $\mathrm{N}$ & $\mathrm{N}$ & $\mathrm{N}$ & $\mathrm{N}$ & $\mathrm{N}$ & $\mathbf{N}$ & $\mathrm{N}$ \\
\hline Cystathionine & 0.03 & 0.02 & 0.02 & 0.02 & $\mathrm{~N}$ & 0.26 & 0.07 & 0.09 & 0.02 & 0.04 \\
\hline Ornithine & 0.09 & 0.08 & 0.17 & $0 \cdot 14$ & $\mathrm{~N}$ & $\mathrm{~N}$ & $\mathbf{N}$ & 0.25 & $\mathrm{~N}$ & $\mathrm{~N}$ \\
\hline Ethanolamine & $0 \cdot 14$ & $0 \cdot 21$ & $0 \cdot 20$ & $0 \cdot 19$ & $1 \cdot 61$ & 0.06 & $\mathrm{~N}$ & $0 \cdot 32$ & $\mathbf{N}$ & $0 \cdot 40$ \\
\hline$\beta$-Alanine & $N$ & $\mathbf{N}$ & Trace & $\mathbf{N}$ & 0.05 & Trace & $\mathrm{N}$ & $\mathrm{N}$ & $\mathbf{N}$ & Trace \\
\hline $\begin{array}{l}\alpha \text {-Amino-adipic } \\
\text { and/or } \alpha \text {-Amino- }\end{array}$ & & & & & & & & & & \\
\hline n-butyric acid & 0.09 & 0.08 & $0 \cdot 11$ & $0 \cdot 14$ & $0 \cdot 22$ & $0 \cdot 27$ & $0 \cdot 20$ & $0 \cdot 24$ & $0 \cdot 29$ & $0 \cdot 14$ \\
\hline acid & $\mathrm{N}$ & $\mathrm{N}$ & $\mathrm{N}$ & $\mathrm{N}$ & 0.22 & 0.40 & $0 \cdot 22$ & 0.04 & 0.60 & 0.28 \\
\hline Total & $4 \cdot 78$ & $4 \cdot 41$ & $7 \cdot 40$ & $7 \cdot 23$ & $11 \cdot 31$ & 13.89 & $7 \cdot 72$ & $10 \cdot 02$ & $10 \cdot 41$ & $8 \cdot 12$ \\
\hline
\end{tabular}

$N$, None detected.

* 'Repeat-breeder' cows.

concentrated to approximately $1 \mathrm{ml}$ in a rotary flash evaporator at $50^{\circ} \mathrm{C}$, and the $\mathrm{pH}$ was adjusted to 7 to 8 by the addition of $1 \mathrm{~N}-\mathrm{NaOH}$. The samples were incubated for $4 \mathrm{hr}$ at room temperature to convert cysteine to cystine. At the end of the incubation period, the $\mathrm{pH}$ of the samples was adjusted to $2 \cdot 0$ by addition of $1 \mathrm{~N}-\mathrm{HCl}$. The samples were then frozen until analysis.

The separation, identification and quantitation of the free amino acids was accomplished by the method of Moore \& Stein (1954) using a Spinco Model 
120 automatic amino acid analyser. The amino acid analyses were done in the Department of Biochemistry, University of Minnesota, St Paul, Minnesota.

\section{RESULTS}

A total of twenty-five free amino acids and amino compounds were identified in uterine fluids (Table 2) while twenty-three were identified in blood serum (Table 3). Qualitative differences were found between samples of uterine fluids and blood sera. Ethanolamine was present in all except two of the

\section{TABLE 3}

CONTENT OF TOTAL FREE AMINO ACIDS AND AMINO GOMPOUNDS IN BOVINE BLOOD SERUM COLLEGTED AT DIFFERENT STAGES OF THE OESTROUS GYCLE $(\mu \mathrm{M} / \mathrm{ml})$

\begin{tabular}{|c|c|c|c|c|c|c|c|c|c|c|}
\hline \multirow[b]{2}{*}{ Amino acid } & \multicolumn{10}{|c|}{ Days of oestrous cycle } \\
\hline & 1 & $1-R B^{*}$ & 2 & $\begin{array}{c}3 \text { to } \\
4\end{array}$ & $\begin{array}{c}5 \text { to } \\
7\end{array}$ & $\begin{array}{r}8 \text { to } \\
10\end{array}$ & $\begin{array}{c}11 \text { to } \\
13\end{array}$ & $\begin{array}{c}14 \text { to } \\
16\end{array}$ & $\begin{array}{c}17 \text { to } \\
18\end{array}$ & $\begin{array}{c}19 \text { to } \\
20\end{array}$ \\
\hline Aspartic acid & 0.01 & 0.04 & 0.01 & 0.02 & 0.02 & 0.02 & 0.01 & Trace & Trace & 0.02 \\
\hline Threonine & 0.07 & 0.05 & $0 \cdot 10$ & $0 \cdot 12$ & $0 \cdot 10$ & 0.05 & 0.07 & 0.07 & 0.04 & 0.05 \\
\hline Serine & 0.09 & 0.07 & 0.15 & 0.18 & $0 \cdot 14$ & $0 \cdot 10$ & $0 \cdot 13$ & $0 \cdot 10$ & 0.05 & 0.08 \\
\hline $\begin{array}{l}\text { Asparagine- } \\
\text { glutamine }\end{array}$ & & & & & & & & & & \\
\hline Proline & $\begin{array}{l}0.30 \\
0.02\end{array}$ & 0.20 & $\begin{array}{r}0.46 \\
0.08\end{array}$ & 0.08 & 0.31 & $\begin{array}{l}0.03 \\
0.94\end{array}$ & $\begin{array}{r}0.31 \\
0.06\end{array}$ & 0.25 & $\begin{array}{l}0.11 \\
0.01\end{array}$ & $\begin{array}{l}0.14 \\
0.07\end{array}-27$ \\
\hline Glutamic acid & 0.08 & 0.06 & $0 \cdot 11$ & 0.26 & 0.14 & $\begin{array}{l}0 \cdot 24 \\
0 \cdot 45\end{array}$ & $\begin{array}{l}0.00 \\
0.12\end{array}$ & 0.07 & $\begin{array}{l}0.01 \\
0.09\end{array}$ & $0 \cdot 11$ \\
\hline Glycine & 0.40 & 0.21 & 0.67 & 0.77 & 0.64 & 0.38 & 0.52 & 0.43 & 0.41 & 0.50 \\
\hline Alanine & 0.22 & $0 \cdot 17$ & $0 \cdot 29$ & 0.40 & $0 \cdot 30$ & 0.23 & 0.33 & $0 \cdot 21$ & 0.21 & $0 \cdot 28$ \\
\hline Valine & 0.16 & $0 \cdot 15$ & $0 \cdot 32$ & 0.23 & 0.22 & $0 \cdot 18$ & 0.31 & 0.23 & 0.20 & $0 \cdot 34$ \\
\hline Cystine & $\mathrm{N}$ & $\mathbf{N}$ & $\mathrm{N}$ & $\mathbf{N}$ & $\mathrm{N}$ & $\mathrm{N}$ & $\mathbf{N}$ & $\mathrm{N}$ & $\mathrm{N}$ & $\mathrm{N}$ \\
\hline Methionine & 0.02 & 0.01 & 0.03 & Trace & 0.02 & 0.02 & 0.02 & 0.02 & 0.02 & Trace \\
\hline Isoleucine & 0.06 & 0.08 & $0 \cdot 17$ & $0 \cdot 17$ & $0 \cdot 16$ & $0 \cdot 11$ & $0 \cdot 15$ & $0 \cdot 13$ & 0.11 & 0.11 \\
\hline Leucine & 0.13 & $0 \cdot 11$ & $0 \cdot 19$ & 0.28 & 0.18 & $0 \cdot 15$ & 0.21 & 0.15 & 0.14 & $0 \cdot 12$ \\
\hline Tyro & 0.05 & 0.05 & 0.09 & $0 \cdot 10$ & 0.09 & 0.06 & 0.07 & 0.06 & 0.05 & $0 \cdot 10$ \\
\hline Phenylalanine & 0.04 & 0.04 & 0.08 & 0.06 & 0.06 & 0.04 & $0 \cdot 06$ & 0.04 & 0.04 & Trace \\
\hline Lysine & 0.08 & $0 \cdot 10$ & $0 \cdot 49$ & $\mathrm{~N}$ & $\mathbf{N}$ & $\mathrm{N}$ & $\mathrm{N}$ & $\mathrm{N}$ & Trace & Trace \\
\hline Histidine & 0.04 & 0.06 & 0.08 & $\mathrm{~N}$ & 0.06 & 0.05 & 0.06 & 0.04 & 0.04 & 0.04 \\
\hline Arginine & 0.13 & $0 \cdot 13$ & 0.21 & 0.12 & 0.18 & 0.16 & 0.16 & 0.11 & $0 \cdot 10$ & $0 \cdot 10$ \\
\hline Taurine & 0.05 & 0.04 & 0.07 & $0 \cdot 14$ & $\mathrm{~N}$ & 0.06 & $\mathrm{~N}$ & 0.04 & $\mathrm{~N}$ & 0.04 \\
\hline Gitrulline & 0.09 & 0.08 & $0 \cdot 16$ & 0.11 & $0 \cdot 14$ & 0.08 & $0 \cdot 16$ & $0 \cdot 11$ & 0.11 & 0.07 \\
\hline Cystathionine & Trace & Trace & Trace & Trace & Trace & Trace & Trace & Trace & Trace & $\mathrm{N}$ \\
\hline Ornithine & 0.04 & 0.06 & 0.07 & 0.02 & $N$ & Trace & 0.07 & $\mathrm{~N}$ & $\mathbf{N}$ & $\mathrm{N}$ \\
\hline Ethanolamine & $\mathrm{N}$ & $\mathrm{N}$ & $\mathrm{N}$ & $\mathrm{N}$ & $\mathrm{N}$ & $\mathrm{N}$ & $\mathrm{N}$ & $\mathrm{N}$ & $\hat{N}$ & $\mathrm{~N}$ \\
\hline$\beta$-Alanine & $\mathrm{N}$ & $\mathrm{N}$ & $\mathrm{N}$ & $\mathrm{N}$ & $\mathrm{N}$ & $\mathrm{N}$ & $\mathrm{N}$ & $\mathrm{N}$ & $\mathrm{N}$ & $\mathrm{N}$ \\
\hline $\begin{array}{l}\alpha \text {-Amino-adipic } \\
\text { and/or } \alpha \text {-amino- }\end{array}$ & & & & & & & & & & \\
\hline n-butyric acid & Trace & $\mathrm{N}$ & 0.03 & $\mathrm{~N}$ & 0.05 & Trace & 0.03 & 0.02 & 0.02 & $\mathrm{~N}$ \\
\hline $\begin{array}{l}\gamma \text {-Amino buty } \\
\text { acid }\end{array}$ & $\Lambda$ & N & $\Lambda$ & $\mathrm{N}$ & 0.0 & $0 \cdot 10$ & $\mathrm{~N}$ & 0.06 & 0.05 & 0.04 \\
\hline Total & 2.08 & $2 \cdot 71$ & 3.86 & 3.41 & $2 \cdot 97$ & 2.51 & $2 \cdot 85$ & $2 \cdot 21$ & 1.80 & $2 \cdot 21$ \\
\hline
\end{tabular}

N, None detected.

* 'Repeat-breeder' cows.

pooled samples of uterine fluid while none was found in the blood serum. $\beta$-Alanine was identified in trace quantities in four of the ten pooled uterine fluid samples and none of the pooled blood serum samples. Cystine was found in uterine fluids during the first 7 days of the oestrous cycle, but none was detected in the blood serum. In contrast, citrulline was identified in all pooled samples of blood serum, but was not found in the uterine fluid samples. 
Text-fig. 1 shows the quantitative distribution of total free amino acids and amino compounds identified in uterine fluid and blood serum throughout the oestrous cycle. The most striking feature in this graph is the quantitative difference between the concentrations in blood serum and uterine fluids. The concentrations of these constituents in uterine fluids were at least one and onehalf times greater than those found in blood serum at all stages of the oestrous cycle. This graph also demonstrates the differences in the concentration of these compounds in the uterine fluids at various stages of the oestrous cycle. The lowest concentration of free amino acids and amino compounds occurred at oestrus while the highest was found at Days 8 to 10 .

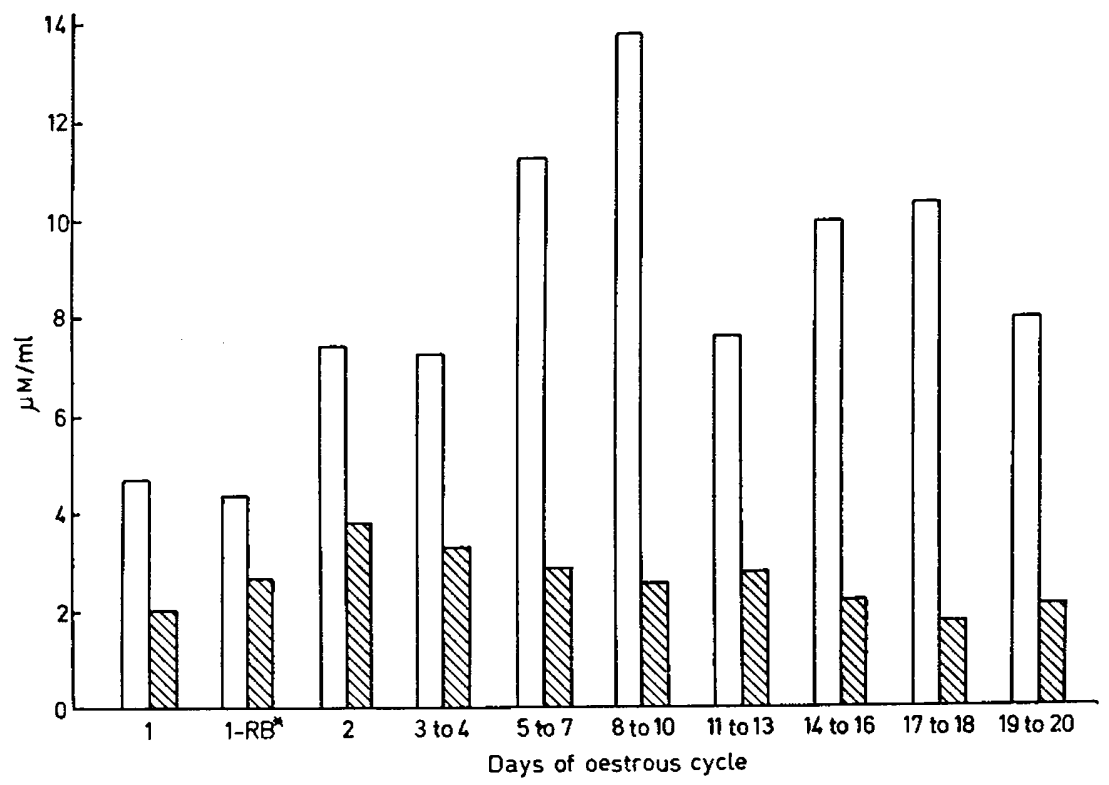

Text-Fig. 1. Comparison of the total free amino acids and amino compounds in bovine uterine fluid (unshaded columns) and blood serum (cross-hatched columns) collected at different stages of the oestrous cycle.

The free amino acid found in the greatest concentration in uterine fluid was glycine. The levels ranged from $0.89 \mu$ moles $(\mu \mathrm{M}) / \mathrm{ml}$ in uterine fluids at the time of oestrus to $4.42 \mu \mathrm{M} / \mathrm{ml}$ in fluids collected between Days 8 to 10 . The levels then decreased to $1.56 \mu \mathrm{m} / \mathrm{ml}$, by Days 19 and 20 . The blood serum level of free glycine remained quite constant throughout the oestrous cycle $(0.21$ to 0.77 $\mu \mathrm{M} / \mathrm{ml})$. Other amino acids that showed changes in concentration during the oestrous cycle included leucine, alanine, phenylalanine, proline, valine, aspartic acid, tyrosine, serine, isoleucine and taurine. The concentration of these amino acids was higher during the luteal phase of the oestrous cycle than in the follicular phase.

The concentration of free glutamic acid in uterine fluids did not show the same pattern of change as that which was found with glycine. During oestrus the free glutamic acid content of the uterine fluids was $0.73 \mu \mathrm{m} / \mathrm{ml}$ and increased to $1.49 \mu \mathrm{M} / \mathrm{ml}$ on the 1 st day post-oestrus. However, throughout the rest of the 
cycle levels remained quite constant, varying between 1.31 and $1.74 \mu \mathrm{M} / \mathrm{ml}$. There was once again a marked difference between the levels in the blood serum and uterine fluids.

While the concentration of the free amino acids in uterine fluid was, in general, several times higher than the concentration found in blood serum, the concentration of one amino acid, arginine, was consistently higher in blood serum than in uterine fluids. The free arginine and methionine concentrations in the uterine fluids were quite low at all stages of the oestrous cycle. Lysine and histidine were present in low concentrations in both uterine fluid and blood serum and were not identified in all samples.

No significant differences in free amino acid levels were found in the uterine fluids taken from normal and repeat-breeder cows at Day 1 of the oestrous cycle.

\section{DISCUSSION}

From the data presented, the quantitative changes of free amino acids in uterine fluids during the oestrous cycle appear to be independent of changes that may occur in the blood serum. The differences between the uterine fluid and blood serum levels support the suggestion that uterine fluids are, at least in part, an active secretion of the uterus. This is further emphasized by the fact that three amino acids identified in uterine fluid were not detected in the blood serum, namely, ethanolamine, $\beta$-alanine and cystine.

The findings in this study agree with the work of Heap (1962), Heap \& Lamming (1962) and Olds \& VanDemark (1957a, b) in suggesting that the uterine fluids in the cow are under hormonal control. The cyclic changes in amino acid concentrations in uterine fluids were evidently not due to a dilution effect at and near the time of oestrus since all amino acid concentrations did not show the same type of cyclic pattern. Free glutamic acid, for example, did not show the same type of change during the oestrous cycle as free glycine.

The significance and role of the free amino acids that are found in uterine fluids is presently unknown. Lutwak-Mann (1959) and Lutwak-Mann, Boursnell \& Bennett (1960) presented results indicating that metabolites in addition to water cross the zona pellucida and associated blastocyst coverings. Gregoire et al. (1961) suggested that the increase of glycine and serine content in uterine fluids of rabbits treated with progesterone may indicate an anabolic effect associated with the growth and development of the ovum. Fridhandler \& Pincus (1959) reported a high concentration of glycine in blastocysts, suggesting that it is absorbed directly from the uterine luminal fluids. The cyclic changes found in the levels of many of the free amino acids in this study support these suggestions with respect to the cow.

Blood serum has been used as the principle medium for the in-vitro storage and handling of ova from the cow (Umbaugh, 1949; Willet, Buckner \& Larson, 1953; Lamming \& Rowson, 1952; Dzuik, Donker, Nichols \& Peterson, 1958; Avery \& Graham, 1962). In view of the differences found between blood serum and uterine fluids in relation to free amino acid content, perhaps a more suitable medium can be developed. Studies relating blood serum and uterine fluid levels 
of other chemical constituents are now being conducted. The changes in concentration of free amino acids in the uterine fluid from day-to-day may aid in the explanation of the importance and necessity for synchronization in the transplantation of ova.

Another possible function for the free amino acids in the uterine fluids is that of providing nourishment for spermatozoa within the female reproductive tract. Bovine spermatozoa are capable of utilizing free glycine (Flipse, 1956). Further, bull semen has been shown to be high in free glutamic acid and glycine (Bhargava, Bishop \& Work, 1959; Larson \& Salisbury, 1953; Johnson, Graham \& Schultz, unpublished data). The levels of these amino acids found in the uterine fluids support the possibility of the fluids playing a nutritional role as suggested by Chang (1959). It is also possible that the amino acids present in these fluids contribute to metabolic processes associated with capacitation.

The fact that no difference was found in the free amino acid content of the uterine fluids obtained at Day 1 of the oestrous cycle from 'repeat-breeder' cows of normal reproductive performance does not exclude the possibility that significant differences may exist during other stages of the cycle. Other chemical constituents and free amino acid concentrations in uterine fluid of normal and 'repeat-breeder' cows should be compared at all stages of the oestrous cycle.

\section{ACKNOWLEDGMENTS}

The authors wish to thank the Louis W. and Maude Hill Family Foundation for their financial support of this project. The work was also supported in part by U.S.P.H.S. Research Fellowship No. 5-F2-GM-15,000, for which gratitude is expressed. The authors appreciate the opportunity for the use of cows in the Minnesota State Institutional and Experiment Station herds for this study.

\section{REFERENCES}

Averx, T. L. \& Graham, E. F. (1962) Investigations associated with the transplantation of bovine ova. III. Recovery and fertilization. 7. Reprod. Fert. 3, 218.

Bhargava, P. M., Bishop, M. W. H. \& Work, T. S. (1959) The chemical composition of bull semen with special reference to nucleic acids, free nucleotides and free amino acids. Biochem. 7. 73, 242.

Chang, M. C. (1959) Fertilizing capacity of spermatozoa. Recent Progress in the Endocrinology of Reproduction. Ed. G. W. Lloyd. Academic Press, New York.

Dzuik, P. J., Donker, J. D., Nichols, J. R. \& Petersen, W. E. (1958) The problems associated with the transfer of ova between cattle. Tech. Bull. Minn. agric. Exp. Stn. No. 222.

Fahning, M. L., Schultz, R. H. \& Graham, E. F. (1966) A technique for collection of uterine fluids from the live cow. Vet. Rec. 79, 230.

FLIPSE, R. J. (1956) Metabolism of glycine by bovine spermatozoa. Science, N.Y. 124, 228.

Fridhandler, H. \& Pincus, G. (1959) Glucose metabolism in rabbit ova, morula and blastocysts. Fedn Proc. Fedn Am. Socs exp. Biol. 18, 1.

Gregoire, A. T., Gonsakdi, D. \& Rakoff, A. E. (1961) The free amino acid content of the female rabbit genital tract. Fert. Steril. 12, 322.

Hammond, J. (1927) The physiology of reproduction in the cow. Cambridge University Press, London.

HEAP, R. B. (1962) Some chemical constituents of uterine washings: A method of analysis with results from various species. F. Endocr. 24, 367.

Heap, R. B. \& Lamming, G. E. (1962) The influence of ovarian hormones on some chemical constituents of the uterine washings of the rat and rabbit. F. Endocr. 25, 57.

Lamming, G. E. \& Rowson, L. E. A. (1952) Superovulation and ovum transplantation in cattle. Proc. 2nd int. Congr. Physiol. Path. Anim. Reprod. Artif. Insem. 1, 144.

Larson, B. L. \& Salisbury, G. W. (1953) The reactive reducing components of semen; the presence of sulfite in bovine semen. F. biol. Chem. 201, 601 . 
LUTWAK-ManN, C. (1959) Biochemical approach to the study of ovum implantation in the rabbit. Mem. Soc. Endocr. 6, 35.

Lutwak-Mann, C., Boursnell, J. C. \& Bennett, J. P. (1960) Blastocyst-uterine relationships: Uptake of radioactive ions by the early rabbit embryo and its environment. F. Reprod. Fert. 1, 169.

Moore, S. \& Stein, W. H. (1954) Procedures for the chromatographic determination of amino acids on four per cent crosslinked sulfonated polystyrene resins. 7. biol. Chem. 211, 893.

Olds, D. M. \& VanDemark, N. L. (1957a) Composition of luminal fluids in bovine female genitalia. Fert. Steril. 8, 345.

Olds, D. M. \& VanDemark, N. L. (1957b) Luminal fluids of bovine female genitalia. F. Am. vet. med. Ass. 131, 555.

Umbaugh, R. E. (1949) Superovulation and ovum transfer in cattle. Am. F. vet. Res. 10, 295.

Willet, E. L., Buckner, P. J. \& Larson, G. L. (1953) Three successful transplantations of fertilized bovine eggs. J. Diary Sci. 37, 520. 